\title{
EHMTI-0233. Clinical characteristics of migraine patients with dopaminergic gene polymorphisms RS1611115
}

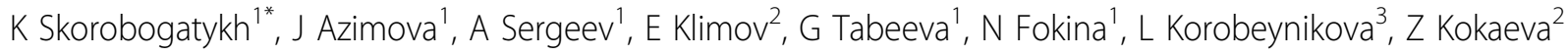 \\ From 4th European Headache and Migraine Trust International Congress: EHMTIC 2014 \\ Copenhagen, Denmark. 18-21 September 2014
}

\section{Introduction}

The dopaminergic system plays a major role in migraine. Dopamine beta hydroxylase (DBH) is responsible for maintaining dopamine-to-norepinephrine ratio implicated in migraine pathophysiology. We aimed to look for association of polymorphisms in dopaminergic genes in genetic susceptibility to migraine in Russian population. In the present study DBH polymorphisms rs1611115 was selected.

The aim of this study was to determine whether the polymorphisms rs1611115 in DBH gene influenced any particular symptoms of the disease.

\section{Methods}

We have analyzed clinical characteristics of 128 patients with migraine (22 patients with migraine with aura and 106 patients with migraine without aura), according to the ICHD-II (2003)) taking into account their genotypes of TT variant of DBH. Genotyping was done using polymerase chain reaction (PCR).

\section{Results}

We have shown that the T-allele carriers $(46,9 \%)$ as compared to the CC genotype patients $(53,1 \%)$, have more severe coarse of migraine. A significant association was shown (number of acute medication per month $(\mathrm{p}=$ $0.04)$, more severe grade of medication overuse $(\mathrm{p}=$ $0.001)$, presence of allodinia $(p=0.03)$ and prodrpomal period $(\mathrm{p}=0.001)$.

${ }^{1}$ University Headache Clinic, University Headache Clinic, Moscow, Russia Full list of author information is available at the end of the article

\section{Conclusions}

Thus, according to our data, the T-allele in rs1611115 is significantly associated with certain clinical characteristics of migraine.

No conflict of interest.

\section{Authors' details}

'University Headache Clinic, University Headache Clinic, Moscow, Russia. ${ }^{2}$ Department of Genetics, Lomonosov Moscow State University, Moscow, Russia. ${ }^{3}$ Department of Genetics, Vavilov Institute of General Genetics of Russian Academy of Sciences, Moscow, Russia.

Published: 18 September 2014

doi:10.1186/1129-2377-15-S1-B35

Cite this article as: Skorobogatykh et al: EHMTI-0233. Clinical characteristics of migraine patients with dopaminergic gene polymorphisms RS1611115. The Journal of Headache and Pain 201415 (Suppl 1):B35.

\section{SpringerOpen $^{\odot}$}

(c) 2014 Skorobogatykh et al; licensee Springer. This is an Open Access article distributed under the terms of the Creative Commons Attribution License (http://creativecommons.org/licenses/by/2.0), which permits unrestricted use, distribution, and reproduction in any medium, provided the original work is properly cited.

Submit your manuscript to a SpringerOpen ${ }^{\circ}$ journal and benefit from:

- Convenient online submission

- Rigorous peer review

- Immediate publication on acceptance

- Open access: articles freely available online

- High visibility within the field

Retaining the copyright to your article

Submit your next manuscript at $>$ springeropen.com 